\title{
Convalescent Plasma Therapy in Severe and Critically III COVID-19 Patients: A Systematic Review and Meta- Analysis
}

\section{Penglei Yang}

Xiangyang No 1 People's Hospital Affiliated to Hubei University of Medicine

Jing Wang

Northern Jiangsu People's Hospital

Ruiqiang Zheng

Northern Jiangsu People's Hospital

Rui Tan

Northern Jiangsu People's Hospital

Xianghui Li

Northern Jiangsu People's Hospital

Xiaoyun Liu

Xiangyang No 1 People's Hospital Affiliated to Hubei University of Medicine

\section{Yang Li}

Xiangyang No 1 People's Hospital Affiliated to Hubei University of Medicine

Jiangquan Yu ( $\square$ yujiangquan2021@163.com )

Northern Jiangsu People's Hospital

\section{Research}

Keywords: Corona Virus Disease 2019, Convalescent Plasma, A Systematic Review and Meta-Analysis.

Posted Date: September 13th, 2021

DOl: https://doi.org/10.21203/rs.3.rs-876454/v1

License: (1) This work is licensed under a Creative Commons Attribution 4.0 International License. Read Full License 


\section{Abstract}

Background: Convalescent plasma treatment of severe and critically ill Corona Virus Disease 2019(COVID-19) patients is still controversial.

Objective: To evaluate the efficacy and safety of convalescent plasma in patients with severe COVID-19 infection and critically ill patients, We performed a meta-analysis and systematic review of convalescent plasma therapy in severe and critically ill COVID-19 patients.

Methods: We conducted a literature search in electronic data and citations of previously published systematic reviews. We included only randomized controlled studies on convalescent plasma for the treatment of severe and critically ill COVID-19 patients.

Results: A total of 7 randomized controlled trials and 1363 patients were included in the meta-analysis. Compared to patients of the control group, there was no difference in clinical improvement (Four studies, RR $1.06,95 \% \mathrm{Cl} 0.96$ to $1.17, \mathrm{p}=0.22$, moderate certainty) and mortality (seven studies, $\mathrm{RR} 0.86,95 \% \mathrm{Cl} 0.66$ to $1.11, p=0.48$, moderate certainty) for patients of convalescent plasma therapy group.

Conclusion: Convalescent plasma does not reduce the improvement of symptoms and the risk of death in severely infected and critically ill COVID-19 patients

\section{Introduction}

COVID-19 infection is a highly contagious and harmful disease. From December 2019 to February 2021, more than one hundred million patients and 2 million deaths are caused by COVID-19 in 210 countries $^{[1]}$. Epidemiology Working Group for NCIP Epidemic Response reported that $14 \%$ of patients would develop severe infections and suffer severe progressive pneumonia and multiple organ failure[2, 3]. There is a lack of effective treatment for COVID-19.

Convalescent plasma was collected from recovered patients with infections[4]. Convalescent plasma was used to treat SARS, the Middle East respiratory syndrome (MERS) [5, 6]. But Convalescent plasma treatment of severe COVID-19 infection is still controversial[2, 7]. A systematic review has reported that convalescent plasma reduces the risk of death in patients with severe COVID-19 disease [8]. However, several RCT studies have reported different results in severely infected patients $[9,10]$. We performed a systematic review and meta-analysis to evaluate the efficacy and safety of convalescent plasma in patients with severe COVID-19 infection and critically ill patients.

\section{Methods}

\section{Registration}

The project was registered on PROSPERO(CRD42021274365). We performed a meta-analysis and systematic review of convalescent plasma transfusion therapy in severe and critical COVID-19 patients.

\section{Information sources}


We conducted a literature search of the following electronic data: PubMed, Cochrane Library, Web of Science, EMBASE. Meanwhile, citations of previously published systematic reviews were searched. The deadline for the search was August 18, 2021.

\section{Search strategy}

We searched for studies using the keywords "COVID-19", "severe acute respiratory syndrome coronavirus 2", "2019-nCoV". "SARS-CoV-2, coronavirus", "convalescent plasma", "convalescent serum," "Plasma immunoglobulins" and so on. Table S1 shows the search process in detail.

\section{Literature inclusion criteria}

We included only randomized controlled studies on convalescent plasma for the treatment of severe and critical COVID-19 patients. Prospective observational studies, retrospective studies, case reports, case series, and retrospective studies were excluded.

\section{Patients inclusion criteria}

(1) COVID-19 diagnosis based on polymerase chain reaction (PCR) testing.

(2) Pneumonia confirmed by chest imaging.

(3) Clinical symptoms meeting the definitions of severe or life-threatening COVID-19.

(4) Severe COVID-19 Respiratory distress (more than 30 breaths/min; in resting state, oxygen saturation of $94 \%$ or less on room air; or arterial $(\mathrm{PaO} 2) /(\mathrm{FiO} 2) \leq 300$. Critical respiratory failure requiring mechanical ventilation, shock, or other organ failures (apart from the lung) requires monitoring intensive care unit (ICU).

\section{Patients excluded criteria}

(1) Pregnancy or lactation

(2) Blood component allergies

(3) Participation in any antiviral clinical trials for COVID-19

\section{Study Selection and Data Extraction}

Two independent reviewers performed a literature search and screening. First, reviewers screened the titles of the literature and then assessed the complete manuscripts. Duplicate references were eliminated. We will extract the following information: $30 \mathrm{~d}$ symptom improvement rate, mortality, $3 \mathrm{~d}$, and $7 \mathrm{~d}$ nucleic acid conversion rate, oxygen support time, hospitalization time, $30 \mathrm{~d}$ discharge rate, and adverse events. Adverse events include severe allergy, severe respiratory and cardiac symptoms, hemolysis, etc. At the same time, patients' basic information was extracted: age, $\mathrm{FiO}_{2}$, SOFA score, plasma usage control method, control group treatment method, etc. If the median and interquartile-range (IQR) were reported for continuous variables in the data, we would convert the data to mean and standard deviation ${ }^{[11,12]}$.

\section{Outcomes}


The primary outcomes included: $30 \mathrm{~d}$ symptom improvement rate and $30 \mathrm{~d}$ mortality rate. Secondary outcomes included: 3-day and 7-day nucleic acid conversion rate, duration of oxygen support, duration of hospital stay, 30-day discharge rate.

\section{Risk of bias assessment and quality evaluation}

The reviewers assessed the risk of bias $(\mathrm{RoB})$ independently using a modified Cochrane RoB tool. Random sequence generation, allocation concealment, blinding method, selective reporting bias, and other biases were evaluated. Risks were classified low, high, and unknown. For the research results, we also performed a GRADE evaluation[13].

\section{Statistics}

Two researchers carried out the data analysis. Mantel-Haenszel statistics and inverse variance models were used in the meta-analysis. Outcome data were analyzed by Review Manager 5.3 for research. The inverse variance model assessed study weights. As a result of dichotomous variables such as mortality, we will calculate the relative risk. We will calculate the mean, standard deviation (SD), and both with $95 \%$ confidence intervals $(\mathrm{Cl})$ for continuous variables. The $\mathrm{x}^{2}$ test, $\mathrm{I}^{2}$, evaluated homogeneity. $\mathrm{I}^{2} \geq 50 \%$ is high heterogeneity. When there was high heterogeneity, we would conduct a sensitivity analysis or use a random model. For the primary outcomes, we would conduct sequential research to evaluate whether the sample size of the results is sufficient. In the trial sequential analysis (TSA), the required information size was based on a type I error of $5 \%$, a beta of $20 \%$, the proportion of participants in the control group with the outcome, and a relative risk reduction of $15 \%$ and $30 \%$.

\section{Subgroup analysis}

Li et al. reported convalescent plasma therapy might be effective for severely infected patients, but it is ineffective for critically ill patients [2]. We performed the subgroup analysis for severe patients and critically ill patients studies in clinical improvement and mortality.

\section{Results}

A total of 832 articles were retrieved, of which 830 were retrieved in electronic data from PubMed, Embase, Web of SCl, and Cochrane Library, and 2 papers were retrieved in a previously published meta-analysis[14, 15].476 records were retrieved after removal of duplicates. By reading the title and abstract, we excluded the unrelated literature on the convalescent plasma treatment of COVID-19. We read the full text and selected studies that met the inclusion criteria, excluded studies that met the exclusion criteria, and studies that data cannot be extracted. A total of 7 randomized controlled trials and 1363 patients were included in the metaanalysis $[2,7,9,14-17]$ (Fig. 1).

Among the included studies, there were conducted in China[2], India[16], Argentina[17], Bahrain[15], Iraq[14], the United States, and Brazil[7, 9]. There only were severe COVID-19 patients in three studies[15-17]. Three were severe and critically ill COVID-19 patients in three studies[2, 7, 9, 14]. Data of Severe patients and critical patients could be extracted separately in two trials[2, 7]. Convalescent plasma was compared to stand treatment in six studies[2, 9, 14-17]. Convalescent plasma was compared to control plasma[7]. anti-SARS- 
CoV-2 antibody titers are tested in all studies[2, 7, 9, 14-17]. Characteristics of the included studies were shown in Table 1. Figure 2 and Fig. 3 showed the details of the RoB of all studies. Table S2 shows the certainty of results.

\section{Primary outcomes}

Compared to patients of the control group, there was no difference in clinical improvement (Four studies, RR $1.06,95 \% \mathrm{Cl} 0.96$ to $1.17, \mathrm{p}=0.22$, moderate certainty) (Fig. 4) and mortality (seven studies, RR $0.86,95 \% \mathrm{Cl}$ 0.66 to $1.11, p=0.48$, moderate certainty) (Fig. 5) for patients of convalescent plasma therapy group. We performed a sequential analysis of mortality. A total of 1,363 patients were included in our study, with an actual sample size of 3,330 required (Fig. 6). Outcome estimates were based on the following statistical indicators: the probability of type I error $(a=0.05)$, probability of type II error $(b=0.2)$, relative risk reduction $(R R R=30 \%)$, and $15 \%$ event rate in the control group. The TSA results showed that the cumulative $Z$ value did not cross the traditional cut-off, nor did it cross the TSA cut-off, nor did it reach the required patient sample size. This indicates that further validation is still needed to verify a difference in safety between the two groups.

\section{Secondary outcomes}

\section{Time of respiratory support}

The trial of Agarwal A and the trial of O'Donnell MR reported on the duration of respiratory support[7, 16]. But data on the time of respiratory support could not be converted to mean and SD. Therefore, we were unable to conduct a meta-analysis of the timing of respiratory support. Compared to control group patients, time of respiratory support of convalescent plasma group patients was no different in the trial of Agarwal A (median 9 days, IQR: 6 to 13 vs. 10 days, IQR: 6 to 13, $p=0.7$ ) and the trial of O'Donnell MR (median 6 days, IQR: 3 to 16 vs. 7 days, IQR:3 to $11, p=0.508$ ). The trial of Sekine $L$ reported on the duration of time without respiratory support, and there was no difference in the duration of time without respiratory support between patients in the convalescent plasma treatment group and control patients.

\section{Time to hospital discharge}

Six trials reported on time to hospital discharge[2, 7, 9, 15-17]. The data of

time to hospital discharge could not be extracted in the trial of Li and Simonovich VA[2, 17]. In the trial of O'Donnell MR, time to hospital discharge could not be converted to mean and SD. The meta-analysis showed no difference in time to hospital discharge (three studies, MD -1.21 day, $95 \% \mathrm{Cl}-4.78$ to $2.36, p=0.51$, very low certainty) (Fig. S1) between patients in the convalescent plasma treatment group and those in the control group.

\section{COVID-19 Nucleic Acid Negative Rate}

Three trials reported negative nucleic acid rates for COVID-19 $[2,9,16]$. Two trials reported the rate of COVID19 nucleic acid negative within $72 \mathrm{~h}[2,16]$. Two trials reported COVID-19 nucleic acid negative rates within 7day $[9,16]$. There was no difference in COVID-19 nucleic acid negative rate at 72h (Two studies, RR 1.62, 95\% 
$\mathrm{Cl} 0.83$ to 3.16, $\mathrm{p}=0.16$, very low certainty) (Fig. S2) and 7d (Two studies, RR 1.19, 95\% Cl 1.00 to 1.40, p = 0.05, low certainty) (Fig. S3) between convalescent plasma therapy group patients and control group patients.

\section{Discharge rate}

Four trials reported discharge rates at 28 or 30 days $[2,7,9,17]$. There was no difference in discharge rate (Four studies, RR 1.06, 95\% Cl 0.96 to 1.17, $p=0.43$, moderate certainty) (Fig. S4) between patients in the convalescent plasma therapy group and those in the control group.

\section{Subgroup analysis}

We performed a subgroup analysis to investigate convalescent plasma therapy on clinical improvement and mortality rate in severe COVID-19 patients and critical COVID-19 patients. In the critical COVID-19 patients, convalescent plasma did not increase rate of clinical improvement (two trials, RR 0.97, 95\% Cl 0.49 to 1.92, p $=0.93$, very low certainty) (Fig. 4) or decrease mortality rate (two trials, RR 0.69, 95\% Cl 0.40 to 1.19, $p=0.18$, low certainty) (Fig. 5). In severe COVID-19 patients, convalescent plasma also did not increase the rate of clinical improvement (Tree trials, RR 1.08, 95\% CI 0.98 to 1.19, $p=0.14$, moderate certainty) (Fig. 4) or reduce mortality (Five trials, RR 0.89, $95 \% \mathrm{Cl} 0.64$ to $1.24, \mathrm{p}=0.49$, moderate certainty) (Fig. 5).

\section{Discussion}

Our study found that convalescent plasma treatment of patients with severe and critical covid-19 infection did not increase the rate of symptomatic improvement, nor did it reduce the risk of death. At the same time, convalescent plasma does not reduce the length of stay in the hospital or the length of time the patient is on oxygen. Convalescent plasma also had no significant effect on the $72 \mathrm{~h}$ nucleic acid conversion rate and 30 day discharge rate, with a tendency to increase the 7-day nucleic acid conversion rate, but there was no statistically significant difference. COVID-19 infection is a highly infectious disease with a high risk of death [18].COVID-19 virus can invade multiple organs, including the lungs, kidneys, liver, heart,brain, and other organs, causing acute respiratory distress syndrome, infectious shock, and multiple organ failure [19]. The lungs are a common target organ, and studies have reported a positive correlation between the severity of lung infections and respiratory viral load [20]. Convalescent plasma reduces viral infectivity by binding to the virus and removes pathogens through various pathways such as complement activation and phagocytosis [21]. Libster et al. reported that early administration of recovery plasma within 3 days in patients presenting with mild disease significantly reduced the risk of progression to severe infection [22]. A recent meta-analysis reported similar findings, with early convalescent plasma reducing the risk of patient death [23].

The use of recovery plasma in severely infected and critically patients remain controversial. Initially, Duan et al. recruited 10 patients with severe COVID-19 infection. They treated them with convalescent plasma transfusions, which resulted in a significant improvement in clinical symptoms, a significant decrease in inflammatory parameters, and an increase in the rate of nucleic acid conversion ${ }^{[24]}$. Subsequently, the FDA issued guidance on the use of convalescent plasma in COVID-19 patients, which also concluded that convalescent plasma could be requested in emergency situations for critically ill patients [25]. Max R et al. included 223 patients, 150 randomized to receive convalescent plasma and 73 to receive normal control 
plasma. It was found that convalescent plasma did not improve clinical symptoms but reduced the risk of death in patients with severe infections [7]. A meta-analysis by Zhang and Sun et al. incorporating observational and retrospective studies came to a similar conclusion that convalescent plasma reduces the risk of death in patients with severe infections [26, 27]. However, recent RCT studies have found that convalescent plasma did not improve the prognosis of patients with severe disease $[9,14-17]$.

In our study, we found that convalescent plasma did not improve clinical symptoms, reduce the risk of death, reduce the time on oxygen, or improve the discharge rate of patients with severe infections and critical illnesses. This may be related to late use and low antibody titers after use $[15,16,23]$. Our study found that convalescent plasma had the potential to increase the $7 \mathrm{~d}$ nucleic acid conversion rate in patients, but its $p=$ 0.05 , which still needs to be further reported in a large sample size study. However, the sequential analysis found that the sample size still fell short of the required sample size, and further study reporting is still needed.

\section{Limitations}

This study has the following limitations: 1 . Antibodies need to be highly specific to function, and we did not consider the effect of the new coronavirus variant on the results of this study. 2. Blood antibody titers following antibody infusion may affect the results. However, studies of adequate antibody titers in severe infections are still too few to group them according to antibody titers, and further research is needed.

\section{Conclusion}

Convalescent plasma does not reduce the improvement of symptoms and the risk of death in severely infected and critically ill patients, nor does it reduce the time on oxygen, the length of hospital stay, or the rate of discharge. There was a trend towards increased 7-day nucleic acid conversion rates in recovery plasma, but this was not statistically significant. The safety and effectiveness of convalescent plasma therapy in severe and critically ill COVID-19 patients still need more research.

\section{Abbreviations}

COVID-19

Corona Virus Disease 2019; SARS:Severe Acute Respiratory Syndrome; MERS:Middle East Respiratory

Syndrome; RCT:randomized controlled trials; PCR:Polymerase Chain Reaction; ICU:Intensive Care Unit; IQR:interquartile-range; RoB:risk of bias; SD:standard deviation; Cl:confidence intervals; TSA:trial sequential analysis; RR:Risk Ratio

\section{Declarations}

\section{Acknowledgments}

None.

\section{Contribution}


PY and JW designed the study and wrote the manuscript; JY revised the manuscript for controversial intellectual content and decided to submit the report. RZ finished the results and wrote some discussions. RT and $\mathrm{XL}$ prepared the figures. $\mathrm{XL}$ and $\mathrm{YL}$ performed a literature search and screening. All authors read and approved the final manuscript.

\section{Funding}

This work was supported by the Yangzhou social development project (YZ2018075), Yangzhou Medical Talent (ZDRC201845).

\section{Availability of data and materials}

All data generated or analyzed during this study are included in this published article.

\section{Ethics approval and consent to participate}

An approval by an ethics committee was not applicable.

\section{Consent for publication}

All authors have agreed to the publication of this manuscript.

\section{Competing interests}

There were no conflicts of interest in this review.

\section{Publisher's Note}

Springer Nature remains neutral concerning jurisdictional claims in published maps and institutional affiliations.

\section{Author Details}

${ }^{1}$ Department of Critical Care Medicine, Xiangyang No. 1 People's Hospital, Hubei University of Medicine, Xiangyang, Hubei, 441000, China. ${ }^{2}$ Graduate school of Dalian Medical University; Department of Critical Care Medicine, Northern Jiangsu People's Hospital, No.98 Nantong West Road, Yangzhou, Jiangsu 225001, China.

${ }^{3}$ Department of Critical Care Medicine, Northern Jiangsu People's Hospital, No.98 Nantong West Road, Yangzhou, Jiangsu 225001, China. ${ }^{4}$ Department of Critical Care Medicine, Northern Jiangsu People's Hospital, No.98 Nantong West Road, Yangzhou, Jiangsu 225001, China. ${ }^{5}$ Department of Critical Care Medicine, Northern Jiangsu People's Hospital, No.98 Nantong West Road, Yangzhou, Jiangsu 225001, China. ${ }^{6}$ Department of Critical Care Medicine, Xiangyang No. 1 People's Hospital, Hubei University of Medicine, Xiangyang, Hubei, 441000, China. ${ }^{7}$ Department of Critical Care Medicine, Xiangyang No. 1 People's Hospital, Hubei University of Medicine, Xiangyang, Hubei, 441000, China. ${ }^{8}$ Clinical Medical College of Yangzhou University, Yangzhou China; Department of Critical Care Medicine, Northern Jiangsu People's Hospital, No.98 Nantong West Road, Yangzhou, Jiangsu 225001, China. 


\section{References}

1. Wang C, Wang Z, Wang G, et al. COVID-19 in early 2021: current status and looking forward. Signal Transduction Targeted Therapy. 2021;6(1):114.

2. Li L, Zhang W, Hu Y, et al. Effect of Convalescent Plasma Therapy on Time to Clinical Improvement in Patients With Severe and Life-threatening COVID-19: A Randomized Clinical Trial. Jama. 2020;324(5):460-70.

3. Epidemiology Working Group for NCIP Epidemic Response, Chinese Center for Disease Control and Prevention. The epidemiological characteristics of an outbreak of 2019 novel coronavirus diseases (COVID-19) in China. Zhonghua Liu Xing Bing Xue Za Zhi. 2020 Feb 10;41(2):145-151. Chinese.

4. Garraud O, Heshmati F, Pozzetto B, et al. Plasma therapy against infectious pathogens, as of yesterday, today, and tomorrow. Transfusion Clinique et Biologique. 2016;23(1):39-44.

5. Arabi YM, Hajeer AH, Luke T, et al. Feasibility of Using Convalescent Plasma Immunotherapy for MERSCoV Infection. Saudi Arabia. 2016;22(9):1554-61.

6. Cheng YWR, Soo YO, et al. Use of convalescent plasma therapy in SARS patients in Hong Kong \%J. European Journal of Clinical Microbiology Infectious Diseases. 2005;24(1):44-6.

7. O'Donnell MR, Grinsztejn B, Cummings MJ, et al.: A randomized, double-blind controlled trial of convalescent plasma in adults with severe COVID-19. The Journal of Clinical Investigation. 2021, 131(13).

8. Meher BR, Padhy BM, Das S, et al. Effectiveness of Convalescent Plasma Therapy in the Treatment of Moderate to Severe COVID 19 Patients: A Systematic Review and Meta-Analysis. J Assoc Phys India. 2020;68(12):35-43.

9. Sekine L, Arns B, Fabro BR, et al. Convalescent plasma for COVID-19 in hospitalised patients: an openlabel, randomised clinical trial. Eur Respir J. 2021 Aug;12:2101471.

10. Lee MJ.Quantifying SARS-CoV-2 viral load: current status and future prospects. Expert review of molecular diagnostics. 2021:1-7.

11. Luo D, Wan X, Liu J, et al. Optimally estimating the sample mean from the sample size, median, midrange, and/or mid-quartile range. Stat Methods Med Res. 2018;27(6):1785-805.

12. Wan $X$, Wang W, Liu J, et al. Estimating the sample mean and standard deviation from the sample size, median, range and/or interquartile range. BMC medical research methodology. 2014;14:135.

13. Khan KS, Borowiack E, Roos C, et al. Making GRADE accessible: a proposal for graphic display of evidence quality assessments. Evidence Based Medicine. 2011;16(3):65.

14. Rasheed AM, Fatak DF, Hashim HA, et al. The therapeutic potential of Convalescent plasma therapy on treating critically-ill COVID-19 patients residing in respiratory care units in hospitals in Baghdad. Iraq. 2020;3:357-66.

15. AlQahtani M, Abdulrahman A, Almadani A, et al. Randomized controlled trial of convalescent plasma therapy against standard therapy in patients with severe COVID-19 disease. Sci Rep. 2021;11(1):9927.

16. Agarwal A, Mukherjee A, Kumar G, et al. Convalescent plasma in the management of moderate covid-19 in adults in India: open label phase II multicentre randomised controlled trial (PLACID trial). 2020, 
371:m3939.

17. Simonovich VA, Burgos Pratx LD, Scibona P, et al. A Randomized Trial of Convalescent Plasma in Covid19 Severe Pneumonia. N Engl J Med. 2021;384(7):619-29.

18. Yang W, Cao Q, Qin L, et al. Clinical characteristics and imaging manifestations of the 2019 novel coronavirus disease (COVID-19): A multi-center study in Wenzhou city, Zhejiang, China. J Infect. 2020;80(4):388-93.

19. Chan C, Foster ST, Chan KG, et al. Repositioned Drugs for COVID-19-the Impact on Multiple Organs. SN comprehensive clinical medicine. 2021:1-18.

20. Liu Y, Yang Y, Zhang C, et al. Clinical and biochemical indexes from 2019-nCoV infected patients linked to viral loads and lung injury. Science China Life sciences. 2020;63(3):364-74.

21. Bloch EM, Shoham S, Casadevall A, et al. Deployment of convalescent plasma for the prevention and treatment of COVID-19. J Clin Invest. 2020;130(6):2757-65.

22. Libster R, Pérez Marc G, Wappner D, et al. Early High-Titer Plasma Therapy to Prevent Severe Covid-19 in Older Adults. 2021, 384(7):610-618.

23. de Candia P, Prattichizzo F, Garavelli S, et al. Effect of time and titer in convalescent plasma therapy for COVID-19. iScience. 2021;24(8):102898.

24. Duan K, Liu B, Li C, et al. The feasibility of convalescent plasma therapy in severe COVID- 19 patients: a pilot study. DOI: 10.1101/2020.03.16.20036145.

25. Recommendations for Investigational COVID-19 Convalescent Plasma. US FDA. Published May 1, 2020. Accessed May 26. 2020. https://www.fda. gov/vaccines-blood-biologics/investigational-newdrug-ind-ordevice-exempti on-ide-process-cber/recommendations-investigational-covid-19-convalescent-plasma.

26. Sun $M, X u Y, H e ~ H$, et al. A potentially effective treatment for COVID-19: A systematic review and metaanalysis of convalescent plasma therapy in treating severe infectious disease. International Journal of infectious diseases: IJID: official publication of the International Society for Infectious Diseases. 2020;98:334-46.

27. Zhang X, Xi L, Pang F, et al. Convalescent Plasma in the Treatment of Severe COVID-19: A Systematic Review and Meta-Analysis. Iranian Journal of public health. 2020;49(11):2022-31.

\section{Tables}

Table 1 Characteristics of included studies. 


\begin{tabular}{|c|c|c|c|c|c|c|}
\hline Trials & Country & Participants & Methods & Intervention & $\begin{array}{l}\text { Convalescent } \\
\text { Plasma }\end{array}$ & Remarks \\
\hline $\begin{array}{l}\text { Ling Li } \\
2020\end{array}$ & China & $\begin{array}{l}103 \text { COVID-19 } \\
\text { patients,45 } \\
\text { severe } \\
\text { patients, and } \\
58 \text { critical } \\
\text { patients. } \\
\text { Age: CP group } \\
70 \text { (62-80) } \\
\text { years } \\
\text { Control group } \\
69 \text { (63-76) } \\
\text { years } \\
\text { Male: CP } \\
\text { group } 51.9 \% \\
\text { Control group } \\
64.7 \% \\
\text { Symptom } \\
\text { onset to } \\
\text { randomization: } \\
\text { CP group 27 } \\
\text { (22-39) } \\
\text { Control group } \\
30 \text { (19-38) }\end{array}$ & RCT & $\begin{array}{l}\text { CP group: The } \\
\text { transfusion } \\
\text { dose of } \\
\text { COVID- } 19 \mathrm{CP} \\
\text { was } \\
\text { approximately } \\
4 \text { to } 13 \mathrm{~mL} / \mathrm{kg} \\
\text { of recipient } \\
\text { body weight. } \\
\text { Control group: } \\
\text { Standard } \\
\text { treatment }\end{array}$ & $\begin{array}{l}\text { only the } \\
\text { plasma units } \\
\text { with an S- } \\
\text { RBD- } \\
\text { specific IgG } \\
\text { titer of at } \\
\text { least } 1: 640 \\
\text { were used for } \\
\text { this study }\end{array}$ & / \\
\hline $\begin{array}{l}\text { Agarwal A } \\
2020\end{array}$ & India & $\begin{array}{l}464 \text { severe } \\
\text { COVID-19 } \\
\text { patients, } \\
\text { Age: CP group } \\
52(42-60) \\
\text { years } \\
\text { Control group } \\
52(41-60) \\
\text { years } \\
\text { Male: CP } \\
\text { group } 75 \% \\
\text { Control group } \\
77 \% \\
\text { Symptom } \\
\text { onset to } \\
\text { randomization: } \\
\text { CP group } 8 \text { (6- } \\
11) \text { days } \\
\text { Control group } \\
8 \text { (6-11) days }\end{array}$ & RCT & $\begin{array}{l}\text { CP group: } \\
\text { Received two } \\
\text { doses of } 200 \\
\text { mL of CP, } \\
\text { transfused } 24 \\
\text { hours apart, in } \\
\text { addition to } \\
\text { the best } \\
\text { standard of } \\
\text { care. } \\
\text { Control group: } \\
\text { Standard } \\
\text { treatment }\end{array}$ & $\begin{array}{l}\text { Nearly two } \\
\text { thirds }(\mathrm{n}= \\
161,64 \%) \text { of } \\
\text { the donors } \\
\text { had a } \\
\text { neutralizing } \\
\text { antibody titer } \\
\text { of more than } \\
1: 20 \text {, with a } \\
\text { titer of } 1: 40 \\
(1: 30-1: 80)\end{array}$ & $\begin{array}{l}348(83 \%) \\
\text { had } \\
\text { detectable } \\
\text { neutralizing } \\
\text { antibodies } \\
\text { at } \\
\text { enrolment. } \\
\text { The } \\
\text { neutralizing } \\
\text { antibody } \\
\text { titre at } \\
\text { enrolment } \\
\text { was } 1: 90 \\
(1: 30- \\
1: 240) \text {. }\end{array}$ \\
\hline
\end{tabular}




\begin{tabular}{|c|c|c|c|c|c|c|}
\hline Trials & Country & Participants & Methods & Intervention & $\begin{array}{l}\text { Convalescent } \\
\text { Plasma }\end{array}$ & Remarks \\
\hline $\begin{array}{l}\text { Simonovich } \\
\text { VA } 2021\end{array}$ & Argentina & $\begin{array}{l}333 \text { severe } \\
\text { COVID-19 } \\
\text { patients, } \\
\text { Age: CP group } \\
62.5 \text { (53-72.5) } \\
\text { years } \\
\text { Control group } \\
62(49-71) \\
\text { years } \\
\text { Male: CP } \\
\text { group } 70.6 \% \\
\text { Control group } \\
61 \% \\
\text { Symptom } \\
\text { onset to } \\
\text { randomization: } \\
\text { CP group } 8 \text { (5- } \\
\text { 10) days } \\
\text { Control group } \\
8 \text { (5-10) days }\end{array}$ & RCT & $\begin{array}{l}\text { CP group: In } \\
\text { patients } \\
\text { weighing }= \\
70 \mathrm{~kg}, 400 \mathrm{ml} \\
\text { volume of } \mathrm{CP} \\
\text { will be } \\
\text { transfused. In } \\
\text { patients } \\
\text { weighing > } 70 \\
\mathrm{~kg}, 600 \mathrm{ml} \\
\text { volume of } \mathrm{CP} \\
\text { will be } \\
\text { transfused at } \\
\text { a rate of } 5 \text { to } \\
10 \mathrm{ml} \mathrm{kg} / \mathrm{h}\end{array}$ & $\begin{array}{l}\text { The total } \\
\text { antibody } \\
\text { titer goal in } \\
\text { convalescent } \\
\text { plasma was } \\
\text { above } 1: 800 \\
\text { in all cases }\end{array}$ & $\begin{array}{l}\text { At two } \\
\text { days: CP } \\
\text { group } \\
\text { neutralizing } \\
\text { antibody: } \\
1: 400 \\
(1: 200- \\
1: 1600) \\
\text { control } \\
\text { group } \\
\text { group } \\
\text { neutralising } \\
\text { antibody: } \\
1: 400(1: 50 \\
-1: 3200), p \\
<0.05\end{array}$ \\
\hline $\begin{array}{l}\text { Sekine L } \\
2021\end{array}$ & Brazil & $\begin{array}{l}160 \text { severe and } \\
\text { critical COVID- } \\
19 \text { patients. } \\
\text { Age: CP group } \\
59.0 \text { (48.0- } \\
68.5) \text { years } \\
\text { Control group } \\
62.0 \text { (49.5- } \\
68.0) \text { years } \\
\text { Male: CP } \\
\text { group } 61.2 \% \\
\text { Control group } \\
55.0 \% \\
\text { Symptom } \\
\text { onset to } \\
\text { randomization: } \\
\text { CP group } 10.0 \\
\pm 3.0 \text { days } \\
\text { Control group } \\
9.8 \pm 3.2 \text { days }\end{array}$ & RCT & $\begin{array}{l}\text { CP group: } \\
\text { Receive two } \\
\text { infusions } 48 \\
\text { hours apart of } \\
300 \text { ml of CP } \\
\text { plus Standard } \\
\text { of Care (SOC) } \\
\text { or SOC alone. }\end{array}$ & $\begin{array}{l}\text { Antibody } \\
\text { titres of } \\
\text { Convalescent } \\
\text { plasma was } \\
1: 320 \\
(1: 160- \\
1: 960) \text {.five } \\
\text { donors' } \\
\text { convalescent } \\
\text { plasma had } \\
\text { lower than } \\
1: 80 \text { (four } \\
1: 40 \text { and one } \\
1: 20 \text { ) }\end{array}$ & $\begin{array}{l}\text { At 3-day: } \\
\text { CP group } \\
\text { neutralising } \\
\text { antibody: } \\
1: 5120 \\
(1: 2560- \\
1: 10240) \\
\text { Control } \\
\text { groups: } \\
1: 2560 \\
(1: 1920- \\
5120) p= \\
0.19)\end{array}$ \\
\hline $\begin{array}{l}\text { O'Donnell } \\
\text { MR } 2021\end{array}$ & $\begin{array}{l}\text { USA and } \\
\text { Brazil }\end{array}$ & $\begin{array}{l}223 \text { COVID-19 } \\
\text { patients, } 195 \\
\text { severe } \\
\text { patients, and } \\
28 \text { critical } \\
\text { patients. } \\
\text { Age } \geq 70: \text { CP } \\
\text { group 28\% } \\
\text { Control group } \\
29 \% \\
\text { Male: CP } \\
\text { group } 64 \% \\
\text { Control group } \\
70 \%\end{array}$ & RCT & $\begin{array}{l}\text { For all } \\
\text { participants } \\
\text { who received } \\
\text { their } \\
\text { treatment } \\
\text { assignment, a } \\
\text { single unit of } \\
\text { plasma }(\sim \\
200-250 \mathrm{ml}) \\
\text { was } \\
\text { transfused } \\
\text { over } \\
\text { approximately } \\
2 \mathrm{~h}\end{array}$ & $\begin{array}{l}\text { There was a } \\
\text { minimum } \\
\text { anti-SARS- } \\
\text { CoV-2 total } \\
\text { lgG antibody } \\
\text { titer of at } \\
\text { least } \\
1: 400 \text { in } \\
\text { convalescent } \\
\text { plasma }\end{array}$ & I \\
\hline
\end{tabular}




\begin{tabular}{|c|c|c|c|c|c|c|}
\hline Trials & Country & Participants & Methods & Intervention & $\begin{array}{l}\text { Convalescent } \\
\text { Plasma }\end{array}$ & Remarks \\
\hline $\begin{array}{l}\text { Anwar M } \\
2020\end{array}$ & Iraq & $\begin{array}{l}49 \text { severe and } \\
\text { critical COVID- } \\
19 \text { patients. } \\
\text { Age: CP group } \\
55.66 \pm 17.83 \\
\text { years } \\
\text { Control group } \\
47.82 \pm 15.36 \\
\text { years } \\
\text { Duration of } \\
\text { infection } \\
\text { before } \\
\text { inclusion in the } \\
\text { study: } \\
\text { CP group } \\
14.80 \pm 7.46 \\
\text { days } \\
\text { Control group } \\
16.57 \pm 5.99 \\
\text { days }\end{array}$ & RCT & $\begin{array}{l}400 \mathrm{~mL} \text { of } \\
\text { frozen } \\
\text { convalescent } \\
\text { plasma were } \\
\text { transfused } \\
\text { over } 2 \mathrm{~h} \text {, only } \\
\text { once for all of } \\
\text { the patients in } \\
\text { the CP group }\end{array}$ & $\begin{array}{l}\text { Only the } \\
\text { donors with } \\
\text { SARS-CoV-2 } \\
\text { lgG index } \\
\text { equal to or } \\
\text { more than } \\
1.25 \text { were } \\
\text { selected }\end{array}$ & $\begin{array}{l}\text { CP group: } 2 \\
\text { patients } \\
\text { with weakly } \\
\text { positive } \\
\text { lgG, } 8 \\
\text { patients } \\
\text { with } \\
\text { moderately } \\
\text { positive, } 11 \\
\text { patients } \\
\text { with } \\
\text { strongly } \\
\text { positive } \\
\text { lgG. } \\
\text { Control } \\
\text { group: } 21 \\
\text { patients } \\
\text { with } \\
\text { negative } \\
\text { lgG, } 7 \\
\text { patients } \\
\text { with weakly } \\
\text { positive } \\
\text { lgG. (p< } \\
0.05 \text { ) }\end{array}$ \\
\hline $\begin{array}{l}\text { Manaf A } \\
2020\end{array}$ & Bahrain & $\begin{array}{l}40 \text { COVID-19 } \\
\text { patients,37 } \\
\text { severe } \\
\text { patients, and } 3 \\
\text { critical } \\
\text { patients. } \\
\text { Age: CP group } \\
52.6 \pm 14.9 \\
\text { years } \\
\text { Control } 50.7 \pm \\
12.5 \text { group } \\
\text { years } \\
\text { Male: CP } \\
\text { group } 85 \% \\
\text { Control group } \\
75 \%\end{array}$ & $\mathrm{RCT}$ & $\begin{array}{l}\text { CP group: The } \\
\text { dosage of CP } \\
\text { was } 400 \mathrm{ml} \text {, } \\
\text { given as } 200 \\
\text { ml over } 2 \mathrm{~h} \\
\text { over } 2 \\
\text { successive } \\
\text { days }\end{array}$ & / & $\begin{array}{l}\text { Patients } \\
\text { who } \\
\text { received } \\
\text { early CP } \\
\text { had titre of } \\
82 \mathrm{AU} / \mathrm{ml} \\
(\mathrm{SD} 23, \mathrm{SE} \\
9.5, \mathrm{~N}=6) . \\
\text { Those who } \\
\text { received CP } \\
\text { after } 3 \\
\text { days had } \\
\text { titre of } 49 \\
\text { AU/ml (SD } \\
58, \mathrm{SE} 22, \\
\mathrm{~N}=7)\end{array}$ \\
\hline
\end{tabular}

\section{Figures}




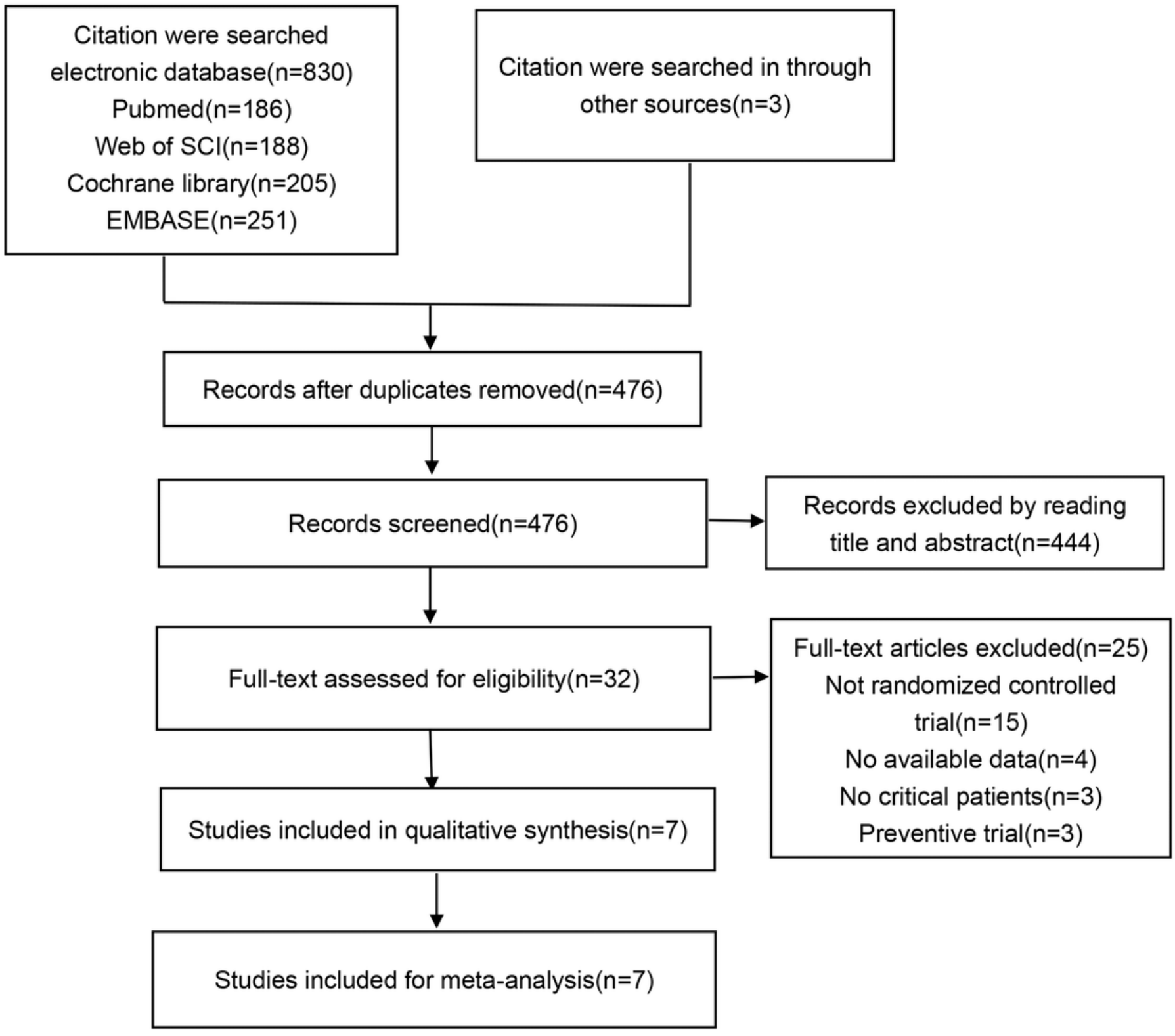

Fig. 1. Flow chart illustrating the study selection process.

Figure 1

Flow chart illustrating the study selection process. 


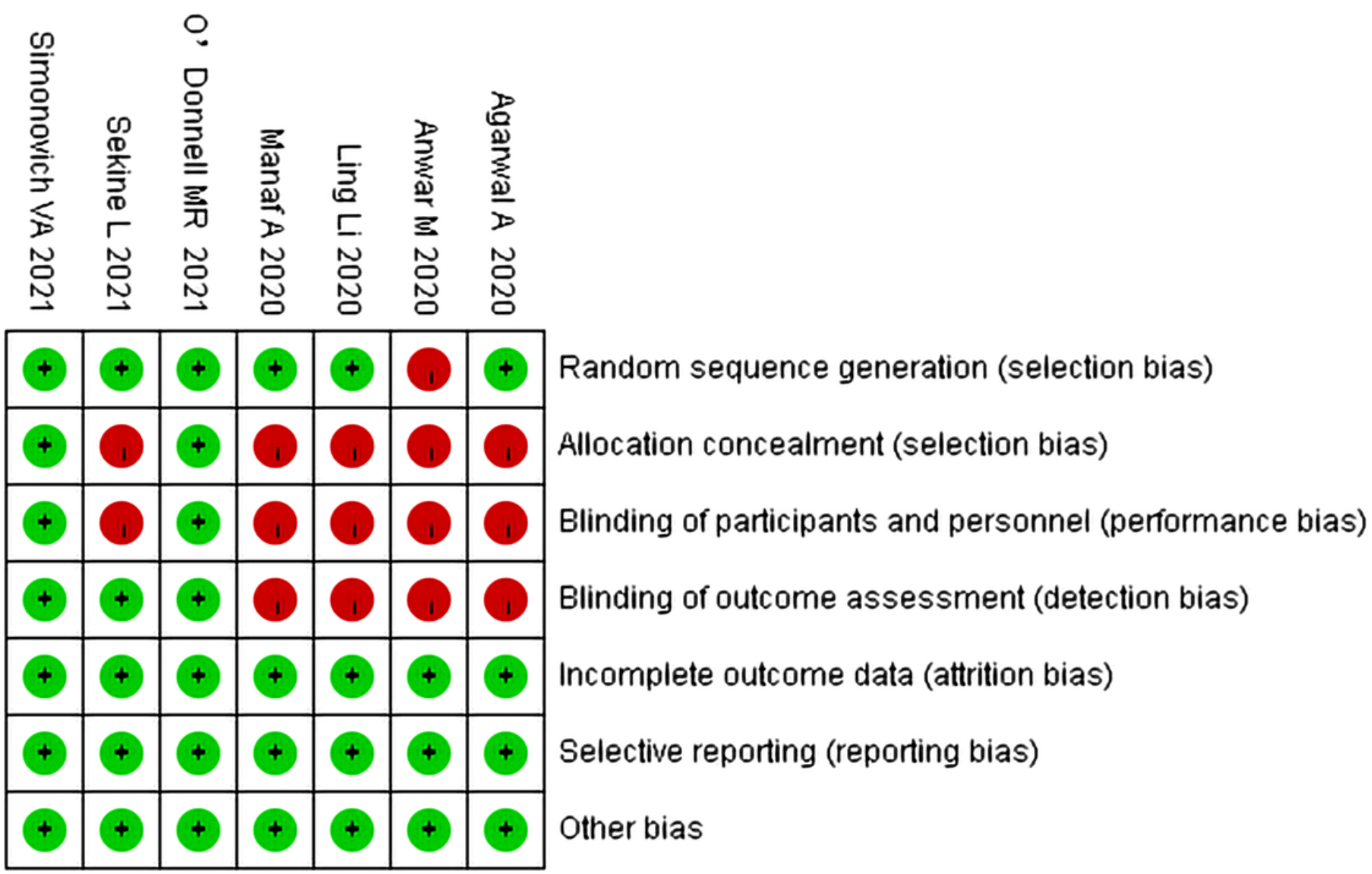

Fig. 2. Risk of bias summary. Review of authors' judgements on the risk of bias items in each included study.

Figure 2

Risk of bias summary. Review of authors' judgements on the risk of bias items in each included study. 
Random sequence generation (selection bias) Allocation concealment (selection bias)

Blinding of participants and personnel (performance bias)

Blinding of outcome assessment (detection bias)

Incomplete outcome data (attrition bias)

Selective reporting (reporting bias)

Other bias

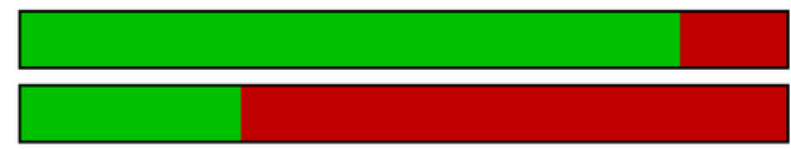

L

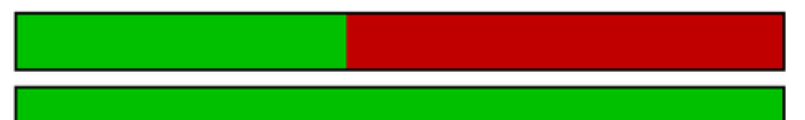

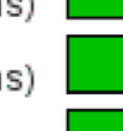

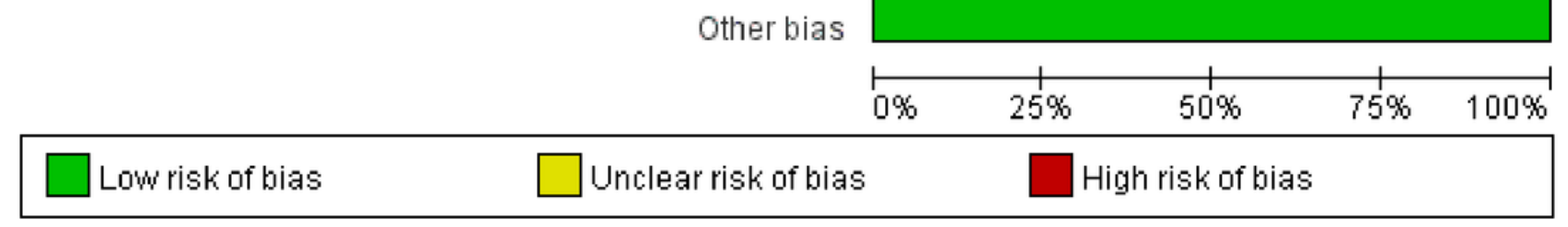

Fig. 3. Risk of bias among the included studies. Review of authors' judgements on the risk of bias items presented as percentages across all the included studies.

\section{Figure 3}

Risk of bias among the included studies. Review of authors' judgements on the risk of bias items presented as percentages across all the included studies. 


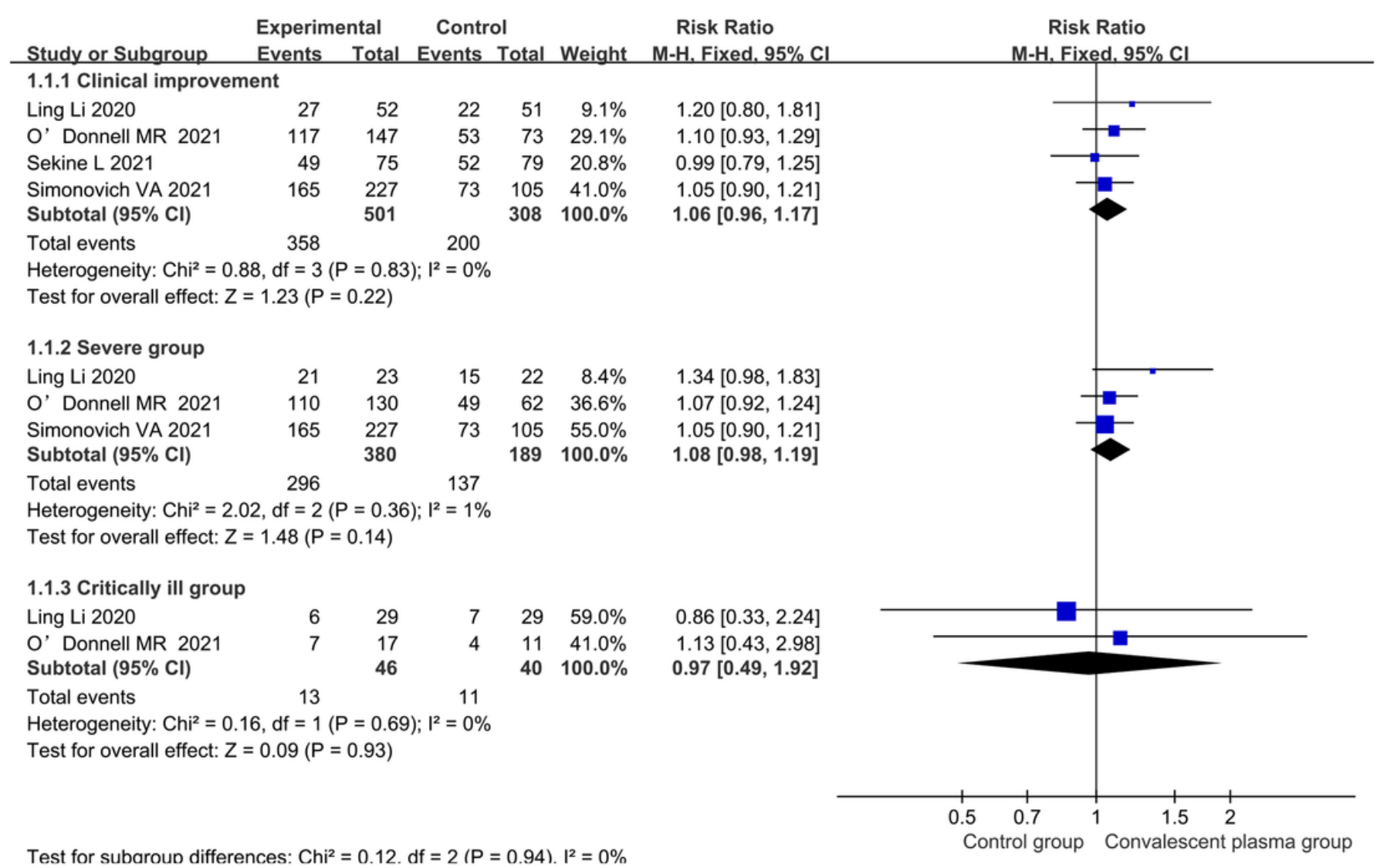

Fig. 4. Forest plot of the clinical improvement between the convalescent plasma therapy group and control group. $\mathrm{M}-\mathrm{H}$, Mantel-Haenszel; $\mathrm{Cl}$, confidence interval; $\mathrm{RR}$, risk ratio.

\section{Figure 4}

Forest plot of the clinical improvement between the convalescent plasma therapy group and control group. $\mathrm{M}-\mathrm{H}$, Mantel-Haenszel; $\mathrm{Cl}$, confidence interval; $\mathrm{RR}$, risk ratio. 


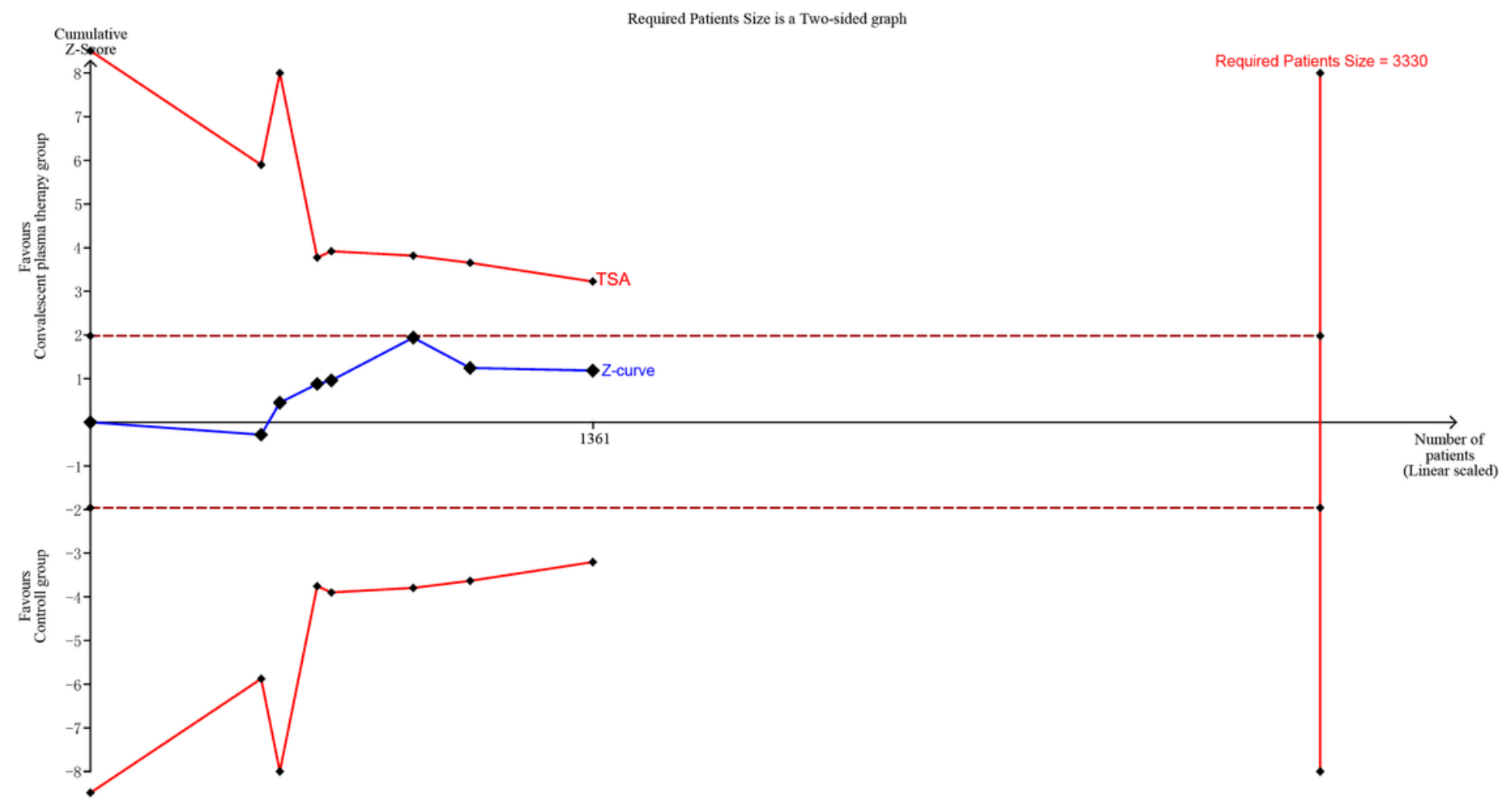

Fig. 6. Results of sequential analysis of mortality. TSA, trial sequential analysis.

\section{Figure 6}

Results of sequential analysis of mortality. TSA, trial sequential analysis.

\section{Supplementary Files}

This is a list of supplementary files associated with this preprint. Click to download.

- TableS1.docx

- Tables2.docx

- Fig.S1.tif

- Fig.S2.tif

- Fig.S3.tif

- Fig.S4.tif 